\title{
The Slovak v The Danish Labor Law Approach to COVID 19 Pandemic
}

\author{
Juraj Hamulák $k^{1} \&$ Denisa Nevická ${ }^{2}$ \\ Comenius University in Bratislava, Slovakia \\ juraj.hamulak@flaw.uniba.sk; denisa.nevicka@flaw.uniba.sk
}

HAMULÁK, Juraj; NEVICKÁ, Denisa. The Slovak v The Danish Labor Law Approach to COVID 19 Pandemic. International and Comparative Law Review, 2020, vol. 20, no. 2, pp. 231-238. DOI: 10.2478/iclr-2020-0026

\begin{abstract}
Summary: The corona virus pandemic affects the functioning of all states. It intervenes in various areas of life, and it is employment relations that we can consider to be the area with the most negative impact. The Slovak Republic is dealing with pandemic in terms of labor law with partial amendments to the Labor Code and a hybrid form of short time working (kurzarbeit). We therefore decided to point out the shortcomings of the legislation in the Slovak Republic as well as to propose solutions that would help alleviate rising unemployment but also adjust the labor market to the demand for modern and flexible forms of work. We also analyzed measures that were chosen by the Kingdom of Denmark to suppress the consequences of the pandemic and, in our opinion, were of a sustainable nature and met the requirements of the labor market subjects.
\end{abstract}

Keywords: Labor Law, Pandemic, Employer, Employee.

\section{Introduction}

The Slovak Republic was the least affected country by the virus pandemic within Europe in terms of the number of infected during the first pandemic wave. At the end of May 2020, the current number of corona virus infections was less than 200 people. However, these very favourable epidemiological statistics changed rapidly after summer. In December 2020 Slovakia had more than 140000 positive cases of COVID-19 and at last 1000 confirmed deaths. The good results from first wave were achieved mainly by strict measures introduced by the state, in particular the wearing of surgical masks, closure of establishments and of borders, restrictions on meetings and many others. Unfortunately, the willingness of people to follow these strict regulations during the second wave is much lower, therefore the higher numbers. To date, the country is on lockdown and

1 Associate Professor at The Comenius University in Bratislava - Faculty of Law, The Department of Labor Law and Social Security Law, Šafaríkovo sq. No. 6, 81000 Bratislava, The Slovak Republic.

2 Assistant Professor at The Comenius University in Bratislava - Faculty of Law, The Department of Labor Law and Social Security Law, Safaríkovo sq. No. 6, 81000 Bratislava, The Slovak Republic. 
most business as well as schools are closed. At the same time, an emergency situation is still declared.

The Slovak labor market is significantly affected by the pandemic of the COVID-19 disease, which also affects labor relations. Statistics show that employers have largely reduced job offers. Areas with highest drop in job offers are tourism, gastronomy, support services and administrative work, some of them by $60 \%$ compared to previous year. ${ }^{3}$ At the same time, many employers have ordered their employees to stay at home due to obstacles at work or a combination of obstacles at work and performance of work. The coronavirus undoubtedly has a devastating impact on the labor market as well as the economy of individual countries. We must add that the government adopted some measures to fight the undesirable effect of the pandemic on labor market. However, were these regulations sufficient? Are there any measures that would help to decrease unemployment? We will try to answer this and many other questions in the next section of our article and compare the labor law approach to pandemic in Slovakia and Denmark.

\section{Measures adopted to suppress the pandemic consequences on labor rela- tions in the Slovak Republic}

Despite the fact that Act no. 311/2001 Coll. The Labor Code (hereinafter also referred to as the "Labor Code") is a very comprehensive legal regulation, provisions governing the procedure for an emergency situation were added to the Labor Code after declaration of an emergency situation. ${ }^{4}$ We dare to state that we consider the above to be incorrect towards employees and employers, as they have the right to know what to expect in the event of an emergency situation. We are of the opinion that if the state decides on the form of Slovak Labor Code, i. e. very comprehensive regulation, the state should de lege ferenda also regulate situations that differ from the usual standards for maintaining the security of employment relations' subjects. The regulations adopted in the shortened legislative procedure proved to be insufficient and had a major (negative) impact on employment.

The provision of the Labor Code, which in times of emergency situation further strengthened the imbalance between employees and the employer are in sec. $250 \mathrm{~b}$ of the Act in question. I does not apply only during the emergency situation but also two months after its end. We have to state that so far, these were the only measures adopted in Labor Code to fight the impact of the pandemic in Slovakia. We could divide them into four categories,

a. work from home;

3 Decline in job offers was published by one of the largest Slovak job portals. [online]. Available at: https://firma.profesia.sk/prisnejsie-opatrenia-opat-spomalili-trh-prace-vyrazny-prepad-vidime-okrem-gastra-cestovneho-ruchu-tiez-v-zakaznickej-podpore-administrative/ Accessed: 07.12.2020.

4 BARANCOVÁ, Helena. a kol. Zákonník práce. Komentár. Bratislava: C. H. Beck, 2019, $1520 \mathrm{~s}$. 
b. obstacles at work and short-time working;

c. protection period;

d. working time and annual leave. ${ }^{5}$

The employer may order the employee to perform work from home, if the type of work allows it, and the employee may also request the performance of work from home from the employer, if not prevented by serious operational reasons. However, the employer is not obliged by law to secure work equipment for the employee. In practice, employees that do not have for example notebook or phone from work, have to use their own, as well as electricity and internet. From our point of view, this is highly insufficient since employers are the ones responsible for quality and safety of workplace. We believe that employees cannot perform their task up to standards if they do not have needed equipment. We are also of the opinion, that health and safety at work standards are at least circumvented, since employers are only rarely checking whether the chairs and tables employees use at home are following regulations or not.

Regarding working time, the employer notifies the employees of the work schedule at least two days in advance. The annual leave from previous year must be agreed at least 2 days before drawing, and the annual leave from this year must be agreed at least a week before drawing if the employee and employer do not agree on another model. As for the fixed-term employment, it can last up to three years during pandemic, unlike the standard two years limitation for fixed-term employment. ${ }^{6}$

Obstacles at work can be used more broadly. If the employee is unable to perform work due to temporary closure of the employer's workplace, he will be entitled to a wage compensation of at least $80 \%$ of his average earnings. However, the employer may still, in agreement with the employees' representatives, reduce the wage compensation to $60 \%$ of the employee's average earnings, but it may not be lower than the minimum wage. ${ }^{7}$ This is a form of short time working model (kurzarbeit) introduced by the Slovak government. If the business was affected by the pandemic, the employer might ask for state funding, up to $80 \%$ of the gross employee's wage. There is no long-term short time working model adopted just yet.

However, many employers have ordered their employees to stay at home due to obstacles at work or a combination of obstacles at work and performance of work, which deprived employees of a legal right to meal. In Slovakia, employee are entitled to meal allowance after more than 4 hours of working. If their work-

5 BARANCOVÁ, Helena. a kol. Zákonník práce. Komentár. Bratislava: C. H. Beck, 2019, $1520 \mathrm{~s}$.

6 FREEL, Lenka. Zamestnávanie zdravotníckych pracovníkov: Podmienky zamestnávania zdravotníckych pracovníkov v Slovenskej republike. Bratislava: právnická fakulta, 2020, pp. 99.

7 BARANCOVÁ, Helena. a kol. Zákonník práce. Komentár. Bratislava: C. H. Beck, 2019, $1520 \mathrm{~s}$. 
ing day is shorter than 4 hours or lasts precisely 4 hours, the do not get meal allowance. This caused a big problem, because not only employees lost $20 \%$ of their wages, but in many jobs, there are not entitled to meal allowances either.

At the same time, a provision was added which obliges the employer to apply the protection period and to maintain the conditions of employment after returning to work also to those employees who personally and fully cared for their relative during emergency situation (i.e., especially a child). This means that employment cannot by terminated by the employer if the employee takes care of a relative. Outside the pandemic, caring for a relative is not considered as protection period and employment can be terminated.

All the above-mentioned provisions were added to the Labor Code during the declaration of the emergency situation, as until the time of the COVID-19 pandemic, the Labor Code did not regulate the procedure for declaring an emergency situation at all. We dare to state that we consider this approach to be incorrect towards the labor relation's subjects, as they have the right to know what to expect in the event of an emergency situation. The year 2020 was extremely chaotic for labor relations due to the absence of legal regulation and uncertainty on the part of both employers and employees. We are of the opinion that if the state opts for the Labor Code in Slovak form, meaning detailed regulation and very comprehensive legislation, the state should de lege ferenda also regulate situations that differ from the usual standards for maintaining the security of the subjects of employment relations. It is these hastily adopted regulations that have had a major impact on employees, and we dare say that especially on female employees. ${ }^{8}$

\section{Exemplary Labor Regulation in the Kingdom of Denmark}

In the middle of 2020, The Eurpoean Foundation for the Improvement of Living and Working Conditions published a study called Living, working and Covid 19. ${ }^{9}$ The study compares the approach to pandemics in individual EU countries and their impact on industrial relations. Based on the consequences of the measures taken on industrial relations and success in stabilizing unemployment, we decided to describe the approach to the COVID-19 pandemic from an employment point of view in Denmark, which maintained one of the lowest unemployment, the prospect that employees will not lose their jobs in the near future and also has a high standard of work-life balance.

Denmark has achieved good results, in particular with regard to the timely agreement between employees 'representatives, employers' representatives and

8 NEVICKÁ, Denisa. Female Worker in Times of Corona Crisis. In Human Rights in the Times of Crisis: State - Society - technology - Security. Poland: Alcide De Gasperi University of Euroregional Economy. 2020. pp. 217-227.

9 HAMULÁK, Ondrej; RAMIRO TROITIÑO, David; CHOCHIA, Archil. Carta de los Derechos Fundamentales de la Unión Europea y los derechos sociales. Estudios Constitucionales, 2018, vol. 16, no. 1, pp. 167-186. 
the government on financial compensation for the private sector of $75 \%-90 \%$ of an employee's gross salary. Targeted assistance to employers in compensating interest-free wages, rescue packages for companies as well as interest-free loans provided by the government brought results that have made Denmark one of the most successful countries in the EU. ${ }^{10}$ It is in the economic field that the most striking difference can be observed compared to the Slovak approach, where aid was rather individualized and thus did not meet the real needs of the labor market.

Another successful tool to curb the effects of a pandemic is working time / remuneration agreements. In Denmark, the employee must either agree to such a change in writing or, if it is unilateral in exceptional circumstances, it must be submitted to him in great advance. Reducing working hours while maintaining the job position was thus one of the most effective tools introduced by the Danish government. ${ }^{11}$ Even if the employees had to stay at home for quarantine or closure, their salary was compensated by the social security system and did not burden the employer. ${ }^{12}$ It is a similar institute as quarantine incapacity for work in the Slovak Republic, but with the difference that in the Slovak Republic employees were entitled to only $55 \%$ of the daily assessment basis. ${ }^{13}$

Another tool for maintaining employment is the use flexibility tools in labor relations. Home office and employee rotation in the workplace were introduced in Denmark almost immediately. Even if the employees had to come to the workplace, then only under strict safety measures, so that as few employees as possible met at the workplace and they were at least 2 meters apart. If employees have been working from home, employers have a legal obligation to provide them with all the necessary equipment to be able to work from home, for example chairs meeting all health standards. At the same time, employers are obliged to consult regularly with employees with regard to their mental well-being. ${ }^{14}$ Although the Slovak Republic has (repeatedly) made a strong home office recommendation, employers do not have an explicit legal obligation to provide employees with working tools for home office work. Thus, many employees could not perform

10 COVID-19: Guidance for Employers in Denmark. [online]. Available at: https://www. twobirds.com/en/news/articles/2020/denmark/covid-19-guidance-for-employers-in-denmark Accessed: 04.01.2021.

11 MARINOV, Marin. Denmark and COVID 19. BSR Policy Briefing Series. Centrum Baltic, 2020, pp. 2-12.

12 COVID-19: Guidance for Employers in Denmark. [online]. Available at: https://www. twobirds.com/en/news/articles/2020/denmark/covid-19-guidance-for-employers-in-denmark Accessed: 04.01.2021.

13 KRIPPEL, Mikuláš. Osobitné podmienky nároku na ošetrovné a podmienky nároku na jeho výplatu. In Gloria et honor et pax omni operanti bonum: Ab imo pectore pocta doc. JUDr. Jánovi Matlákovi, CSc. Bratislava: Právnická fakulta UK. 2020. pp. 151-167.

14 Employment 2020: Denmark. [online]. Available at: https://practiceguides.chambers.com/ practice-guides/employment-2020/denmark/trends-and-developments Accessed: 04.01.2021. 
their work properly from home, they did not have adequate technical equipment, which will have an impact not only on their health but also on their financial evaluation or employment stability.

Strict hygiene measures, flexibility but also targeted state aid make Denmark the country with the least impact on employment and the labor market within the EU.

\section{Reflections de lege ferenda}

As shown in measures adopted by more successful country, as Denmark undoubtedly is, the first essential and necessary step in responding to the current situation is to start preparing measures that will at least help maintain employment and prevent the loss of thousands of jobs. In the Slovak republic, unemployment was at the rate of $5.15 \%$ before the onset of the pandemic. In November 2020 , the rate of unemployment was $8,14 \%$. The most critical situation is among working students because one in three of them lost their job. ${ }^{15}$ The measures taken by the Slovak Republic in an effort to prevent the spread of COVID-19 have and will have a long-term adverse effect on employment.

This could be partially prevented by the already mentioned amendment to the Labor Code, which shall enshrine the procedure in the event of an emergency situation and not just hastily adopted provisions in the shortened legislative procedure. Furthermore, we are of the opinion that if the Slovak Republic supported flexible forms of work in the long run, the adaptation of employees and employers to an emergency situation would be much easier. It is therefore necessary to adapt regulations and policies responding to the new conditions as soon as possible and to focus on the flexibility elements of the employment relationship, which is almost absent in the Slovak Republic legislation. The urgency is characterized by the need to prevent an increase in unemployment, which secondarily leads to social dependence and an increase in poverty. ${ }^{16}$ To this end, it is crucial to prepare a set of measures that will not only focus on reducing labor costs but will prioritize the introduction of modern and often not fully standard employment relationships.

It is also necessary to reconsider the mechanism of raising the minimum wage, which in the current situation we do not consider affordable for employers. The primary challenge for labor law at the time of the COVID-19 pandemic is to take measures to enable work to be performed atypically, i.e., part-time work, casual work, or other flexible forms of employment. All the above areas of Slo-

15 The Central Office of Labor, Social Affairs and Family. [online]. Available at: https://www. upsvr.gov.sk/statistiky/nezamestnanost-mesacne-statistiky/2020.html?page_id=971502 Accessed: 07.12.2020

16 CAPÍKOVÁ, Silvia, NOVÁKOVÁ, Mária. Challenging COVID-19 times - possibilities and limitations of law in regulation of health behavior of individuals. In: Crisis as a challenge for human rights. Bratislava: Univerzita Komenského v Bratislave, 2020, pp. 13-32. 
vak regulation have been constructed mainly for the traditional concept of the employee-employer relationship, fixed 8 working hours and the personal presence of the employee at the workplace. Unlike in Denmark, where employees and employers have much broader flexibility when it comes to labor arrangements as well as working hours.

We also consider important the modernization of the divided work and the removal, respectively, reduction of the administrative burden of the employer in its application. It is an atypical form of employment, which is regulated in the Slovak Labor Code in a very unsuitable and unfavorable way, which causes its zero use in practice. If the legislation in question were amended, it would be a unique form of employment that would allow flexible employment of parents, students, people with disabilities or pensioners. It is these categories of employees who are most at risk of redundancies and consequent unemployment. ${ }^{17}$ Another possibility of fast and flexible employment is the use of digitization in a group form of work called "crowd working". ${ }^{18}$ In the Slovak Republic, a similar form of employment is not regulated. Application of "crowd working" would contribute to increased demand for labor and participation of large number of job seekers while maintaining social security.

Unfortunately, we must state that we consider the adoption of labor standards in the form of by-laws to be a new and fatal problem that arose during a pandemic in the Slovak republic. It is inconceivable that in democracy and rule of law, the government should adopt labor law regulations in the form of a decree of the Chief Hygienist. This is confusing for employers, and in the event of future labor disputes, it cannot be ruled out that employers will be unsuccessful in disputes with employees due to incorrect government action. We are of the opinion that the state should submit labor law norms in the ordinary legislative procedure, in exceptional circumstances in the shortened legislative procedure, but always after negotiations with tripartite, which is not currently happening in the Slovak Republic.

\section{Conclusion}

The role of labor legislation is to reduce the effects of the crisis, to focus on legislative changes, both in active labor market policies and employment services, and the introduction of new flexible forms of employment, which employers have been calling for many years. It is at this time of crisis that they prove to be very necessary. Knowing the effects of the crisis, state policy must therefore focus on three basic areas: 1. employment protection legislation, 2. subsequently to address

17 SUPPA, Alessandro, BUREŠ, Pavel. Can Multinational Corporations be responsible for human violation of its outsourcee company? Response of national or international law? In International and Comparative Law Review. Volume 20: Issue 1. 2020, pp. 153-179.

18 MESARČÍK, Matúš. Právne aspekty spoločného zdroja údajov v kontexte zefektívnenia správy zdravotníctva. In Justičná revue, 2018, pp. 733-743. 
the impact and support the increase of employment, and finally, 3. to introduce new forms of employment that will help to overcome effect of so called "relapse". The COVID-19 pandemic has brought many challenges for labor law. We are convinced that thorough analysis and comparison with Danish legislation, we were able to show that the Slovak labor law was not prepared for the pandemic, nor were the measures adopted sufficient. The unemployment rate is still increasing, while job offers are rapidly decreasing. Some might state that the vaccination will come as "light at the end of the tunnel" but the opposite seems to be true. According to national survey, only $27 \%$ of people would be willing to get vaccination against SARS-COV-2 at the end of November 2020. It is our opinion, that following the danish example, we shall adopt more flexible forms of employment, that will enable work from home in flexible hours and provide employees with necessary tools. We consider home office, work on demand, crowd working as well as divided work to be the best options. It is not possible for the state to fund the labor market indefinitely, therefore we need to adopt flexible types of employment as soon as possible, to prevent even more adverse impact of the pandemic.

\section{List of references:}

BARANCOVÁ, Helena. a kol. Zákonník práce. Komentár. Bratislava: C. H. Beck, 2019.

CAPÍKOVÁ, Silvia, NOVÁKOVÁ, Mária. Challenging COVID-19 times - possibilities and limitations of law in regulation of health behavior of individuals. In: Crisis as a challenge for human rights. Bratislava: Univerzita Komenského v Bratislave, 2020, pp. 13-32.

FREEL, Lenka. Zamestnávanie zdravotníckych pracovníkov: Podmienky zamestnávania zdravotníckych pracovníkov v Slovenskej republike. Bratislava: právnická fakulta, 2020.

HAMULÁK, Ondrej; RAMIRO TROITIÑO, David; CHOCHIA, Archil. Carta de los Derechos Fundamentales de la Unión Europea y los derechos sociales. Estudios Constitucionales, 2018, vol. 16, no. 1, pp. 167-186.

KRIPPEL, Mikuláš. Osobitné podmienky nároku na ošetrovné a podmienky nároku na jeho výplatu. In Gloria et honor et pax omni operanti bonum: Ab imo pectore pocta doc. JUDr. Jánovi Matlákovi, CSc. Bratislava: Právnická fakulta UK. 2020. pp. 151-167.

MARINOV, Marin. Denmark and COVID 19. BSR Policy Briefing Series. Centrum Baltic, 2020, pp. 2-12.

MESARČÍK, Matúš. Právne aspekty spoločného zdroja údajov v kontexte zefektívnenia správy zdravotníctva. In Justičná revue, 2018, pp. 733-743.

NEVICKÁ, Denisa. Female Worker in Times of Corona Crisis. In Human Rights in the Times of Crisis: State - Society - technology - Security. Poland: Alcide De Gasperi University of Euroregional Economy. 2020. pp. 217-227.

SUPPA, Alessandro, BUREŠ, Pavel. Can Multinational Corporations be responsible for human violation of its outsourcee company? Response of national or international law? In International and Comparative Law Review, 2020, vol 20, no 1, pp. 153-179. 